\title{
EVALUATION OF LIQUID INGESTION AFTER BARIATRIC SURGERY
}

\author{
Roberto Oliveira DANTAS, Leda Maria Tavares ALVES, Rachel de Aguiar CASSIANI and \\ Carla Manfredi dos SANTOS
}

\begin{abstract}
Context - Bariatric surgery is an effective treatment for obesity; however, after surgery the patient may have difficulty in swallowing liquid and solid foods. Objectives - To evaluate liquid ingestion in patients who had undergone bariatric surgery. Method - We studied 43 volunteers with normal body mass index (BMI) (BMI: 18.5-24.9 kg/m²), 55 subjects with class III obesity (BMI: $>40.0 \mathrm{~kg} / \mathrm{m}^{2}$ ), and 48 subjects with bariatric surgery for treatment of class III obesity. The method chosen for evaluation was the water swallowing test. The subjects drank in triplicate $50 \mathrm{~mL}$ of water while being precisely timed and the number of swallows were counted. Results - There was no difference between subjects with normal BMI and subjects with class III obesity. During the first 2 months after bariatric surgery the patients showed an increase in the time needed to drink the entire volume, in the number of swallows, and in the inter-swallow interval, and a decrease in the volume swallowing capacity (volume/swallowing) and swallowing flow rate (volume swallowed/second). After 2 months, the results of the swallowing measurements moved in the direction of normal values. Conclusion - Bariatric surgery may cause more intense alterations of liquid bolus swallowing within 2 months after the procedure, which moved to normal values after this time.
\end{abstract}

HEADINGS - Drinking. Bariatric surgery. Obesity.

\section{INTRODUCTION}

Obesity is an increasing worldwide problem which does not always show a good response to clinical treatment ${ }^{(23)}$. The complications consequent to obesity are life threatening and need intervention.

For patients with class III obesity, with a body mass index (BMI) over $40 \mathrm{~kg} / \mathrm{m}^{2(21,28)}$, bariatric surgery represents the most effective therapeutic option ${ }^{(4,5)}$. After surgery the patients may have some degree of difficulty in swallowing liquid and solid foods ${ }^{(27)}$, which is supposed to be consequent to the gastric alterations caused by the surgery.

Our hypothesis was that, after bariatric surgery for the treatment of class III obesity, the patients may have difficulty in swallowing liquids caused by the reduction of gastric volume. Our aim in this study was to evaluate liquid ingestion in class III obese subjects and in subjects who had undergone bariatric surgery for the treatment of class III obesity.

\section{METHODS}

We studied 43 normal volunteers ( $79 \%$ women) with a BMI of $18.6-24.9 \mathrm{~kg} / \mathrm{m}^{2}$ (mean: $21.4 \pm 1.8 \mathrm{~kg} /$ $\mathrm{m}^{2}$ ), aged 22-66 years (mean: $36.2 \pm 12.8$ years), and 55 subjects $(80 \%$ women) with a BMI of 40.1-72.2 $\mathrm{kg} / \mathrm{m}^{2}$ (mean $51.8 \pm 10.2 \mathrm{~kg} / \mathrm{m}^{2}$ ), aged $25-64$ years (mean $40.4 \pm 10.9$ years). No subject had dysphagia or gastrointestinal diseases. We also studied 48 patients (77\% women) aged 27-64 years (mean: $45.1 \pm 11.4$ years), who had bariatric surgery for the treatment of class III obesity. In 18 patients ( $78 \%$ women) the surgery was performed 9-63 days (median: 21 days) before the swallowing evaluation (Group I); the surgery was performed 91-284 days (median: 104 days) before evaluation (Group II) in 12 patients ( $75 \%$ women), and 350-2631 days (median 578 days) before the swallowing evaluation in 18 patients ( $78 \%$ women) (Group III). The surgery was a vertical banded gastroplasty with gastric bypass $^{(6,7)}$. The investigation was approved by the Human Research Committee of the University Hospital of Ribeirão Preto, SP, Brazil and written informed consent was given by all subjects, whose anonymity was preserved.

For the evaluation of swallowing we used the water swallowing test ${ }^{(1,2,8,17)}$. All subjects were evaluated in the sitting position. They were asked to drink 50 $\mathrm{mL}$ of water from a plastic cup "as quickly and as comfortably as possible" while being precisely timed. The chronometer was started when the first drop of water touched the lip, and was stopped when the larynx of the volunteers came to rest and they breathed. The volunteers performed sequential swallows without any breaks during each measurement. The swallowing test was performed in triplicate, with an interval of at least

Department of Medicine, Medical School of Ribeirão Preto, University of São Paulo, Ribeirão Preto, SP, Brazil.

Correspondence: Prof. Roberto Oliveira Dantas - Departamento de Clínica Médica da Faculdade de Medicina de Ribeirão Preto - USP - $14049-900$ - Ribeirão Preto, SP Brazil. E-mail: rodantas@fmrp.usp.br 
30 seconds between measurements. The result for each subject was the mean of the three measurements. The researchers involved in the swallowing evaluation had previous training in timing the water ingestion and in counting the number of swallows, determined from the upper movements of the larynx. Each evaluation was performed with the simultaneous participation of at least two researchers. The senior researcher measured the duration of ingestion and counted the number of swallows. The others counted the number of swallows.

In addition to the time and number of swallows needed to ingest $50 \mathrm{~mL}$ of water we calculated: a) inter-swallow interval: the time to complete the task, in seconds, divided by the number of swallows during the task; b) swallowing flow rate: volume drunk $(\mathrm{mL})$ divided by the time taken in seconds; swallowing volume capacity: volume drunk $(\mathrm{mL})$ divided by the number of swallows. We also quantified the number of subjects with slow swallowing. We defined slow swallowing when the subjects took more than 9 seconds (approximately the mean plus two standard deviations of non-operated subjects) to ingest the entire volume of $50 \mathrm{~mL}$. We obtained the weight of the patients from the medical records on the day before surgery and all volunteers were weighed on the day of swallowing evaluation.

Statistical analysis was performed at the Quantitative Methods Center (CEMEQ) of the Medical School of Ribeirão Preto, USP, using the mixed-effects linear model ${ }^{(26)}$ with adjustment by the PROC MIXED SAS software, version $9^{(22)}$. Data are reported as mean $\pm \mathrm{SD}$. The differences were considered significant when $P<0.05$ in a two-tailed statistical analysis.

\section{RESULTS}

There was no difference between the results of class III obese subjects and of subjects with normal BMI (Table 1). During the first 2 months after bariatric surgery (Group I) the patients showed an increase in the time to drink water, in the number of swallows and in the inter-swallow interval, and a decrease in swallowing volume capacity (Figure 1) and in swallowing flow rate (Figure 2). Two months after surgery the swallowing measurements moved in the direction of the values found in subjects who had not had bariatric surgery. In group III the mean time to ingest all the volume and the inter-swallow interval were greater than in non-operated subjects yet $(P<0.05)$.

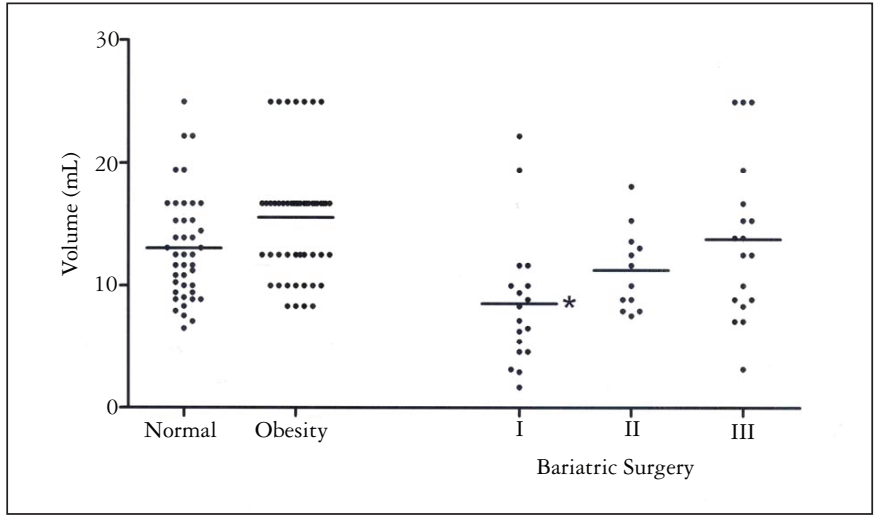

FIGURE 1. Swallowing volume capacity of subjects with normal BMI, class III obese subjects, and patients who had undergone bariatric surgery. The horizontal bars represent the mean. $* P<0.05$. Group I vs normal, obese and group III subjects

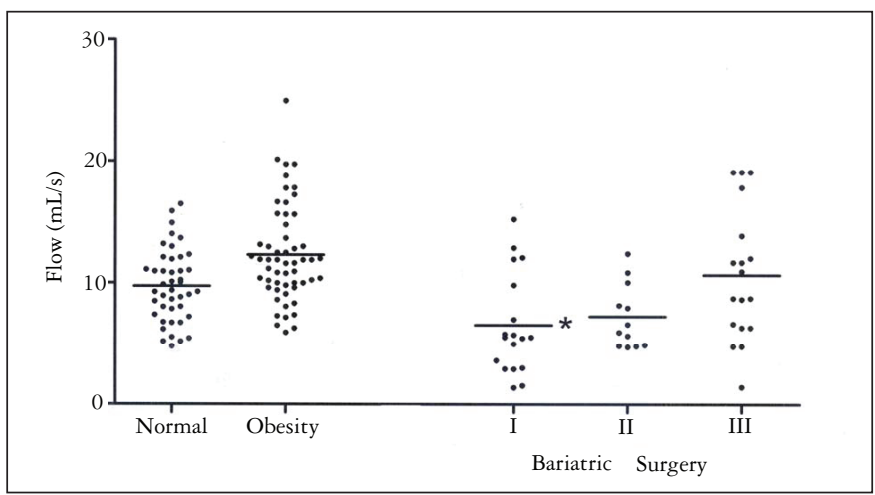

FIGURE 2. Swallowing flow rate of subjects with normal BMI, class III obese subjects, and patients who had undergone bariatric surgery. The horizontal bars represent the mean. $* P<0.05$. Group I vs normal, obese and group III subjects

Figure 3 shows the correlation between time and weight loss in patients with and without slow swallowing. Subjects with slow swallowing tended to lose more weight than subjects who took less than 9 seconds to ingest the water $(P$ $=0.07)$. Slow swallowing was observed in $3(7.0 \%)$ subjects with normal BMI, $3(5.8 \%)$ subjects with class III obesity, 9 $(50.0 \%)$ subjects of group I, $4(33.3 \%)$ subjects of group II,

TABLE 1. Results of swallowing evaluation (mean \pm SD)

\begin{tabular}{lccccc}
\hline & \multicolumn{5}{c}{ Bariatric surgery } \\
\cline { 2 - 6 } & $\begin{array}{c}\text { Normal } \\
(\mathbf{n}=43)\end{array}$ & $\begin{array}{c}\text { Class III obesity } \\
(\mathbf{n}=55)\end{array}$ & $\begin{array}{c}\text { Group I } \\
(\mathbf{n}=18)\end{array}$ & $\begin{array}{c}\text { Group II } \\
(\mathbf{n}=12)\end{array}$ & $\begin{array}{c}\text { Group III } \\
(\mathbf{n}=18)\end{array}$ \\
\hline Duration of ingestion(s) & $5.5 \pm 1.7^{\mathrm{a}}$ & $5.2 \pm 2.2^{\mathrm{a}}$ & $11.2 \pm 7.8^{\mathrm{b}}$ & $7.8 \pm 2.6$ & $7.6 \pm 7.4$ \\
Number of swallows & $4.2 \pm 1.4^{\mathrm{c}}$ & $4.2 \pm 1.6^{\mathrm{c}}$ & $7.0 \pm 3.6^{\mathrm{b}}$ & $4.9 \pm 1.3$ & $4.9 \pm 3.3$ \\
Inter-swallow interval(s) & $1.3 \pm 0.3^{\mathrm{a}}$ & $1.3 \pm 0.3^{\mathrm{a}}$ & $1.5 \pm 0.5$ & $1.6 \pm 0.3$ & $1.5 \pm 0.3$ \\
Swallowing flow rate $(\mathrm{mL} / \mathrm{s})$ & $10.0 \pm 3.0^{\mathrm{d}}$ & $12.3 \pm 3.8^{\mathrm{d}}$ & $6.4 \pm 4.4^{\mathrm{b}}$ & $7.2 \pm 2.7$ & $10.0 \pm 5.1$ \\
Volume capacity $(\mathrm{mL})$ & $13.2 \pm 4.7^{\mathrm{c}}$ & $15.5 \pm 4.8^{\mathrm{c}}$ & $9.1 \pm 5.3^{\mathrm{b}}$ & $11.0 \pm 3.7$ & $13.8 \pm 6.6$ \\
\hline
\end{tabular}

$\mathrm{a}-P<0.05$ vs groups I, II and III. $\mathrm{b}-P<0.05$ vs group III. $\mathrm{c}-P<0.05$ vs group I. $\mathrm{d}-P<0.05$ vs groups I and II. 
and $3(16.7 \%)$ subjects of group III. Time had a significant influence on weight loss $(P<0.01)$, whereas age $(P=0.45)$ and gender $(P=0.75)$ had no influence.

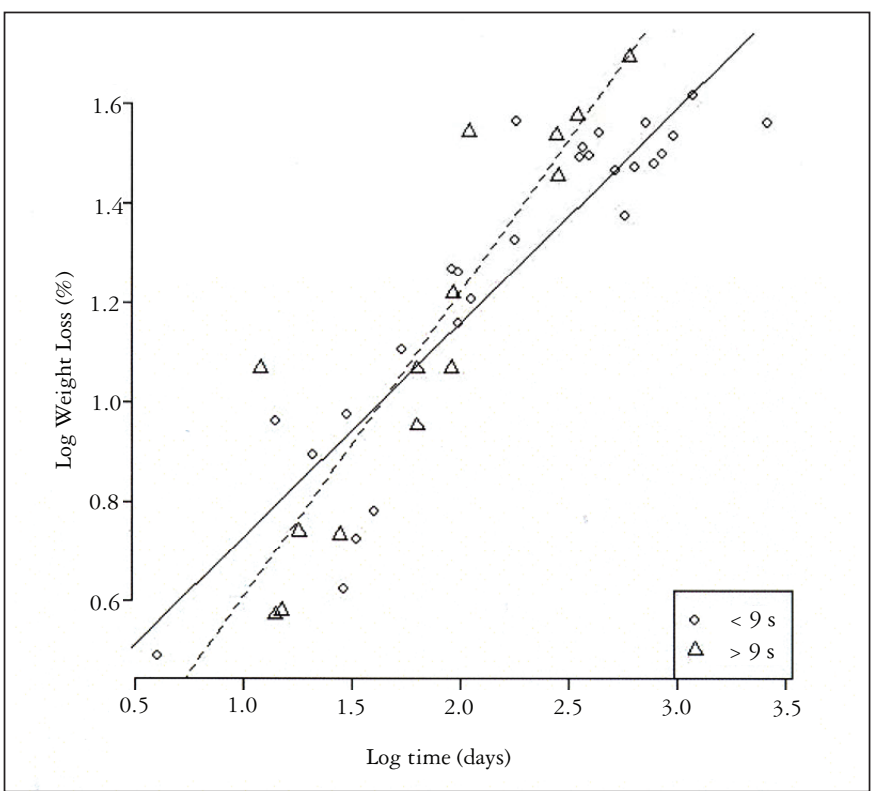

FIGURE 3. Correlation between time and weight loss in patients who took more than 9 seconds to ingest water (broken line) and patients who took less than 9 seconds to ingest water (solid line). $(P=0.07)$

\section{DISCUSSION}

We found a significant alteration of swallowing in the group of operated subjects within 2 months after bariatric surgery, with a return to values close to those of non-operated subjects in the group evaluated after 1 year.

After bariatric surgery the volume of the stomach was reduced $^{(6,7)}$, a fact that did not permit a rapid ingestion of liquid or solid foods. The results suggested that the difficulty in ingesting the liquid may be associated with the weight loss, with people with a longer duration of ingestion tending to lose more weight over time than people with a shorter duration of ingestion.

Obesity causes changes in gastrointestinal motility ${ }^{(30)}$. The gastric capacity of obese subjects is greater than that of normal weight subjects, with significantly larger stomachs in obese than in non-obese subjects ${ }^{(13,14,15)}$, a fact that may be an adaptive response to overeating ${ }^{(15)}$. This situation is not seen after bariatric surgery but, taking into consideration the present results, gastric capacity should partially increase from the small volume initially seen after the surgery.

More important than gastric capacity is gastric accommodation for the determination of the amount of food intake. Impaired gastric accommodation is associated with upper gastrointestinal symptoms such as early satiety ${ }^{(30)}$. Several studies did not find differences in the gastric accommodation of obese subjects compared to controls ${ }^{(18,19,30)}$, a fact that should change after surgery due to the small volume of the remaining stomach. There is evidence that obese subjects have accelerated gastric emptying $^{(30)}$ related to overeating and obesity ${ }^{(11)}$. The rapid emptying reduces the presence of food inside the stomach and precipitates a feeling of hunger, reducing the interval between consecutive meals ${ }^{(30)}$.

Gastric capacity is significantly reduced to $20-30 \mathrm{~mL}$ after bariatric surgery such as gastric bypass ${ }^{(12)}$. The weight loss is a consequence, at least in part, of this gastric restriction. The very small gastric pouch produces early satiety and a consequent reduction in food intake, a situation that changes the behavior of the patients during the meals. It has been suggested that gastric bypass markedly suppresses the response of the orexigenic gastric hormone ghrelin to fasting, contributing to the anorectic effect observed following gastric bypass ${ }^{(9)}$, but this has not been demonstrated in other investigations ${ }^{(12)}$. Other hormones arising from the small intestine also suppress appetite and influence food intake ${ }^{(12)}$.

The small size of the gastric pouch appears to be the cause of the longer duration of ingestion and of the increased number of swallows needed to ingest the entire water volume. This avoids the rapid arrival of water into the pouch. Similar results have been observed in another situation where the transit through the esophagus is impaired and the water cannot go into the stomach, such as esophageal achalasia caused by Chagas' disease ${ }^{(10)}$.

Obesity is associated with an increased rate of transient lower esophageal sphincter relaxation and increased postprandial gastroesophageal reflux, with the reflux possibly being due to an increase in intragastric pressure ${ }^{(24,29)}$. The increase in intragastric pressure may cause impairment of esophageal peristalsis ${ }^{(25)}$. Although it is possible to see alterations in esophageal motility in obese subjects ${ }^{(16,20)}$, the swallowing dynamics does not differ between them and normal BMI subjects $^{(3)}$, indicating that a possible increase in intragastric pressure of non-operated obese subjects is not sufficient to change swallowing and should not be an explanation for the alterations seen after the surgery.

The restriction of rapid ingestion of liquid and solid foods after surgery is an expected situation, part of a change of learned behavior for the adjustment of the patients to the operative procedure ${ }^{(12)}$. The restriction influences weight loss and may explain, at least in part, the weight stabilization occurring some time after surgery, when the patients seem to recover partially their ability to ingest food. Of the 48 individuals subjected to bariatric surgery included in this investigation, $16(33.3 \%)$ had slow swallowing, taking more than 9 seconds to drink a $50 \mathrm{~mL}$ volume of water, showing that this is a frequent finding after the surgery, even after a follow-up of more than 1 year.

The method used here, the water swallowing test, is easy to perform, inexpensive and of good reproducibility ${ }^{(2)}$ and has been used in the evaluation of swallowing in various situations $^{(1,2,3,8,17)}$. It has limitations but is effective for the demonstration of swallowing difficulties ${ }^{(8,17)}$.

In conclusion, bariatric surgery causes alterations in liquid ingestion which may be involved in the weight loss. 
Dantas RO, Alves LMT, Cassiani RA, Santos CM. Avaliação da ingestão de líquido após cirurgia bariátrica. Arq Gastroenterol. 2011;48(1):15-8.

RESUMO - Contexto - Cirurgia bariátrica é tratamento efetivo para a obesidade. Após a operação o paciente pode ter dificuldade em ingerir alimentos líquidos e sólidos. Objetivo - Avaliar a ingestão de líquido em pacientes submetidos a cirurgia bariátrica. Métodos - Estudaram-se 43 voluntários com índice de massa corporal (IMC) normal $\left(18,9-24,5 \mathrm{~kg} / \mathrm{m}^{2}\right), 55$ sujeitos com obesidade classe III (IMC: $>40.6 \mathrm{~kg} / \mathrm{m}^{2}$ ), e 48 sujeitos que haviam sido submetidos a cirurgia bariátrica para tratamento de obesidade classe III. Utilizou-se na avaliação o teste de deglutição de água. Os sujeitos ingeriram $50 \mathrm{~mL}$ de água enquanto o tempo de ingestão era medido e contado o número de deglutições. Resultados - Não houve diferença entre os sujeitos com IMC normal e pacientes com obesidade classe III. No grupo de pacientes avaliados até 2 meses após a operação os pacientes tinham, em média, aumento do tempo para ingerir todo volume de água, no número de deglutições, e no intervalo entre deglutições, e diminuição do volume em cada deglutição e do fluxo de ingestão. Após 2 meses as medidas tiveram tendência a se aproximar dos valores encontrados nos sujeitos não operados. Conclusão - Cirurgia bariátrica pode provocar alterações na deglutição de líquidos nos primeiros 2 meses após o procedimento, tendendo a se aproximar dos valores normais após este período.

DESCRITORES - Ingestão de líquidos. Cirurgia bariátrica. Obesidade.

\section{REFERENCES}

1. Alves LM, Cassiani Rde A, Santos CM, Dantas RO. Gender effect on the clinical measurement of swallowing. Arq Gastroenterol. 2007;44:227-9.

2. Alves LMT, Cassiani RA, Santos CM, Dantas RO. Avaliação da deglutição pelo teste de ingestão de água. GED Gastroenterol Endosc Dig. 2007;26:1-4.

3. Alves LMT, Santos CM, Cassiani RA, Dantas RO. Dinâmica da deglutição de líquido em pessoas obesas. GED Gastroenterol Endosc Dig. 2007;26:187-90.

4. Brolin RE. Update: NIH consensus conference. Gastrointestinal surgery for severe obesity. Nutrition. 1996;12:403-4.

5. Buchwald H. Overview of bariatric surgery. J Am Coll Surg. 2002;194:367-75.

6. Capella RF, Capella JF, Mandec H, Nath P. Vertical banded gastroplasty-gastric bypass: preliminary report. Obes Surg. 1991;1:389-95.

7. Capella JF, Capella RF. The weight reduction operation of choice: vertical banded gastroplasty or gastric bypass? Am J Surg. 1996;117:74-9.

8. Chee C, Arshad S, Singh S, Mistry S, Hamdy S. The influence of chemical gustatory stimuli and oral anaesthesia on healthy human pharyngeal swallowing. Chem Senses. 2005;30:393-400.

9. Cummings DE, Weigle DS, Frayo RS, Breen PA, Ma MK, Dellinger EP, Purnell JQ. Plasma ghrelin levels after diet-induced weight loss or gastric bypass surgery. N Engl J Med. 2002;346:1623-30.

10. Dantas RO, Alves LMT, Cassiani RA, Santos CM. Clinical measurement of swallowing and proximal esophageal contraction in Chagas' disease. Esophagus. 2009;6:231-6.

11. Duggan JP, Booth DA. Obesity, overeating, and rapid gastric emptying in rats with ventromedial hypothalamic lesions. Science. 1986;231:609-11.

12. Elder KA, Wolfe BM. Bariatric surgery: a review of procedures and outcomes. Gastroenterology. 2007;132:2253-71.

13. Geliebter A. Gastric distension and gastric capacity in relation to food intake in humans. Physiol Behav. 1988;44:665-8.

14. Geliebter A, Hashim SA. Gastric capacity in normal, obese, and bulimic women. Physiol Behav. 2001;74:743-6.

15. Granstrom L, Blackman L. Stomach distension in extremely obese and in normal subjects. Acta Chir Scand. 1985;151:367-70.

16. Hong D, Khajanchee YS, Pereira N, Lockhart B, Patterson EJ, Swanstrom LL. Manometric abnormalities and gastroesophageal reflux disease in the morbidly obese. Obes Surg. 2004;14:744-9.
17. Hughes TA, Wiles CM. Clinical measurement of swallowing in health and in neurogenic dysphagia. QJM. 1996;89:109-16.

18. Kim DY, Camilleri M, Murray JA, Stephens DA, Levine JA, Burton DD. Is there a role for gastric accommodation and satiety in asymptomatic obese people? Obes Res. 2001;9:655-61.

19. Klatt S, Pieramico O, Güthner C, Ditschuneit HH, Glasbrenner B, Beckh K, Adler G. Proximal gastric motility functions are normal in severe obesity. Digestion. 1997;58:115-9.

20. Koppman JS, Poggi L, Szomstein S, Ukleja A, Botoman A, Rosenthal R. Esophageal motility disorders in the morbid obese population. Surg Endosc. 2007;21:761-4.

21. Korner J, Klein S, Aronne LJ. Approach to the patient with obesity. In: Yamada T. Alpers DH, Laine L, Kaplowitz N, Owyang C, Powell DW, editors. Textbook of gastroenterology. Philadelphia: Lippincott Williams \& Wilkins; 2003. p. $752-60$

22. Littell RC, Milliken GA, Stroup WW, Wolfinger RD, editors. SAS system of non-linear mixed models. Cary, NC: SAS Institute; 1996.

23. Ogden CL, Yanovski SZ, Carroll MD, Flegal KM. The epidemiology of obesity. Gastroenterology. 2007;132:2087-102.

24. Pandolfino JE, El-Serag HB, Zhang Q, Shah N, Ghosh SK, Kahrilas PJ. Obesity: a challenge to esophagogastric junction integrity. Gastroenterology. 2006;130:63949.

25. Ren JL, Dodds WJ, Martin CJ, Dantas RO, Mittal RK, Harrington SS, Kern MK, Brasseur JG. Effect of increased intra-abdominal pressure on peristalsis in feline esophagus. Am J Physiol. 1991;261:G417-25.

26. Schall R. Estimation in generalized linear models with random effects. Biometrika. 1991;78:719-27.

27. Suter M, Calmes JM, Paroz A, Giusti V. A new questionnaire for quick assessment of food tolerance after bariatric surgery. Obes Surg. 2007;17:2-8.

28. World Health Organization - WHO. Obesity: preventing and managing the global epidemic. Geneva: WHO, 1997. (Report the WHO Consultation of Obesity).

29. Wu JCY, Mui LM, Cheung CMY, Chan Y, Sung JJ. Obesity is associated with increased transient lower esophageal sphincter relaxation. Gastroenterology 2007;132:883-9.

30. Xing J, Chen JD. Alterations of gastrointestinal motility in obesity. Obes Res. 2004;12:1723-32.

Received 26/3/2010. Accepted 1/6/2010 